DOI: $10.4274 /$ tpa.842

\title{
Sağlık meslek lisesi öğrencilerinin beslenme alışkanlıklarının, beslenme bilgi düzeylerinin ve vücut bileşimlerinin değerlendirilmesi
}

\author{
Evaluation of body compositions, dietary habits and nutritional \\ knowledge of health college students
}

\author{
Fatma Nişancı Klınç, Deniz Çağdaş* \\ Türkiye Yüksek Ihtisas Hastanesi, Beslenme ve Diyet Bölümü, Ankara, Türkiye \\ *Hacettepe Üniversitesi Tip Fakültesi, Çocuk Sağığı ve Hastallkları Anabilim Dall, Çocuk Immünoloji Bölümü, Ankara, Türkiye
}

\section{Özet}

Amaç: Sağlık Meslek Lisesi'nde eğitim alan ergenlik çağındaki kızların beslenme alışkanlıklarının, beslenme davranışlarına yönelik bilgi düzeylerinin, besin tüketim durumlarının ve vücut bileşimlerinin değerlendirilmesi amaçlandı.

Gereç ve Yöntem: Bu çalışma Sağlık Meslek Lisesi'ndeki 14-17 yaş arası 172 kız öğrenci üzerinde yapılmış, ergenlerin antropometrik ölçümleri ve vücut bileşimleri ölçülmüş ve beslenme bilgi düzeyleri, beslenme alışkanlıkları, besin tüketim sıklıkları ve bir günlük besin tüketim durumları için bir anket uygulanmıştır.

Bulgular: Vücut kitle indeksi (VKi) persantiline göre ergenlerin \%13,9'unun kilolu ve şişman olduğu, \%20,7'sinin bel çevresinin 90. persantilin üzerinde olduğu, \%13,9'unun sistolik kan basıncının, \%5,8'inin diyastolik kan basıncının 95. persantilin üzerinde olduğu, \%19,8'inin sistolik ya da diyastolik kan basınçlarının 95. persantilin üzerinde olduğu saptanmıştır. Ergenlerin \%63,9'unun üç öğün yemek yediği, \%41,1'inin her gün kahvaltı yapmadığı saptanmıştır. Enerji ve besin öğeleri tüketimleri incelendiğinde, \%28,9'unun yetersiz ve \%5,3'ünün fazla enerji tükettikleri, $\% 5,3$ 'ünün yetersiz ve \%6,6'sının fazla karbonhidrat tükettikleri, \%35,5'inin yetersiz ve \%16,3'ünün fazla protein tükettikleri saptanmıştır. Ergenlerin yaklaşık üçte birinin besin tüketimi konusunda uygun olmayan tutum ve davranış gösterdikleri ve besin içeriği konusunda bilinçsiz oldukları görülmüştür.

Çıkarımlar: Olumlu beslenme davranışının kazanılması çocukluk çağından başlayan uzun bir süreçtir. Çalışmamızda ergenlerin öğrenci grubunda beslenme alışkanlıkları ve besin tüketimleri konusundaki bilgi ve tutumları sağlık meslek lisesinde eğitim almalarına rağmen yeterli düzeyde değildi. Bu nedenle okullarda düzenli ve devamlı beslenme eğitim programlarının düzenlenmesi önem taşımaktadır. (Türk Ped Arş 2012; 47: 181-8)

Anahtar sözcükler: Antropometrik ölçümler, beslenme alışkanlıkları, ergen, şişmanlık, vücut bileşimi

\section{Summary}

Aim: Our aim was to evaluate nutritional habits, knowledge of nutritional attitudes, nutritional consumption, and body composition of medical career college students.

Material and Method: The study included 172 female medical career college students. Anthropometric measurements, body composition, knowledge of nutrition, nutritional habits, frequency of food consumption and daily food consumption were evaluated.

Results: According to body mass index (BMI) percentiles, $13.9 \%$ were overweight-obese; $20.7 \%$ had waist circumference above the 90 th percentile; $13.9 \%$ had systolic blood pressure (BP) above the 95th percentile, $5.8 \%$ had diastolic BP above the 95th percentile and $19.8 \%$ had systolic or diastolic BP above the 95th percentile. It was observed that $63.9 \%$ of the students had meals 3 times a day and $41.1 \%$ did not have breakfast at all. Energy consumption was inadequate in $28.9 \%$ and excessive in $5.3 \%$. Carbohydrate consumption was inadequate in $5.3 \%$ and excessive in $6.6 \%$. Protein consumption was inadequate in $35.5 \%$ and excessive in $18.4 \%$. Approximately $1 / 3$ of the students had improper attitudes about food consumption and they were unaware of food ingredients.

Conclusions: Achievement of proper feeding behavior begins from childhood. Even though they were receiving education in a health-related field, they possessed poor knowledge regarding eating habits and their attitude towards healthy diet was not promising. Therefore, regular educational programs about nutrition should be provided in schools. (Turk Arch Ped 2012; 47: 181-8)

Key words: Adolescent, anthropometric measurements, body composition, eating habits, obesity

Yazışma Adresi/Address for Correspondence: Dr. Fatma Nişancı Klınç, Türkiye Yüksek ỉhtisas Hastanesi, Beslenme ve Diyet Bölümü, Ankara, Türkiye E-posta: fnisanci@mynet.com Geliş Tarihi/Received: 18.12.2011 Kabul Tarihi/Accepted: 04.04.2012

Türk Pediatri Arşivi Dergisi, Galenos Yayınevi tarafından basılmıştır. / Turkish Archives of Pediatrics, published by Galenos Publishing 


\section{Giriş}

Ergenlik dönemi, 10-19 yaş grubu olarak tanımlanmaktadır. Bu dönem büyüme ve gelişmenin en hızlı olduğu, çocukluktan erişkinliğe geçişi kapsayan özel bir dönemdir (1). Hızlı büyüme ve gelişme, enerji ve besin öğelerine olan ihtiyacı arttırırken, artan ihtiyaçlarının karşılanmasında çeşitli sorunlar ortaya çıkabilmektedir (2,3). Bu sorunların bir bölümü gencin yaşam şekliyle, bir bölümü ise bilinçsizlik nedeni ile kazanılan yanlış alışkanlıklarla ilgili olabilir. Günümüzde gençlerin biyolojik ve psikososyal sağlık sorunları arasında, sağlıksız, dengesiz beslenme alışkanlığı ve buna bağlı gelişen hastalıklar ilk sıralarda yer almaktadır (4).

Sağlıklı beslenme gibi yaşam biçimi davranışları genellikle ergenlik döneminde kazanılır ya da yeniden şekillenir. Bu alışkanlıkları genellikle aile, akranlar ve media gibi birçok etmen etkilemektedir (2,3). Düzensiz öğün, öğün aralarında atıştırma, ev dışında yemek yeme alışkanlığı ve ayaküstü beslenme (fast-food) ergenlik dönemi beslenme alışkanlıklarının tipik özellikleridir (1).

Ergenler kimlik arayışı içerisindedir, bağımsız olmaya ve kabul görmeye çabalar ve dış görünüşleri ile fazla ilgilidirler $(2,3)$. Bu dönemde yanlış uygulanan zayıflama diyetleri yetersiz ve dengesiz beslenmeye neden olur. Diğer yanlış alışkanlıklardan biri de öğün atlamadır. En çok atlanan öğün ise en önemli öğün olan sabah kahvaltısıdır. Yetersiz ve dengesiz beslenmenin öğrencilerin dikkat sürelerini kısaltıp algılamalarını azalttığı, öğrenmede güçlüğe ve davranış bozukluklarına, okula devamsızlık ve okul başarısında düşmeye neden olduğu bildirilmektedir (3).

Türkiye'de okul çağındaki çocuk ve gençler arasında zayıflık, şişmanlık ve ilgili sorunlar, metabolik sendrom, avitaminozlar, anemi, basit guatr ve diş çürükleri beslenme ile ilişkili sorunlar arasında yer almaktadır (4). Sağlık meslek lisesinde sağlık açısından diğer liselere göre daha yoğun eğitim almakta olan geleceğin anneleri ergenlerin beslenme alışkanlıklarının, beslenme davranışlarına yönelik bilgi düzeylerinin, besin tüketim durumlarının ve vücut bileşimlerinin değerlendirilmesi amacıyla bu araştırma planlanmıştır.

\section{Gereç ve Yöntem}

Çalışmada Ocak 2009 döneminde Pursaklar ve Çubuk Sağlık Meslek Lisesi'ndeki 14-17 yaş arası kız öğrenciler değerlendirilmiş, bu öğrencilerin antropometrik ölçümleri ve vücut bileşimleri ölçülerek beslenme bilgi düzeyleri, beslenme alışkanlıkları, besin tüketim sıklıkları ve bir günlük besin tüketim durumları bir anket uygulanarak değerlendirilmiştir.

Antropometrik olarak vücut ağırlığı, boy uzunluğu, bel ve kalça çevresi ölçülmüş, diğer ölçümler için vücut bileşimi analiz cihazı kullanılmıştır.

Vücut kitle indeksi (VKI) persantilleri, Öztürk ve ark. (5) hazırladığı 6-18 yaş arası Türk çocuklarının yaşa ve cinse özel VKI persantil değerleri kullanılarak saptanmıştır. Vücut kitle indeksi 95. persantilin üzerinde olan çocuklar şişman, 85-95. persantil arasında olanlar kilolu, 5-85. persantil arasında olanlar normal ağırlıklı, 5. persantilin altındakiler ise düşük ağırlıklı olarak değerlendirilmiştir (6).

Bel çevresi persantilleri, Hatipoğlu ve ark. (7) hazırladığı 717 yaş arası Türk çocuklarının yaşa ve cinse özel bel çevre persantil eğrileri kullanılarak saptanmıştır. Bel çevresinin boya oranı da her öğrenci için hesaplanmıştır (8).

Öğrencilerin yağ yüzde persantilleri, sağlıklı Türk çocukları için belirlenen yağ yüzde persantilleri kullanılarak belirlenmiştir (9). Yağ yüzde persantil eğrilerine göre kız çocukları için 10. persantilin altı düşük ağırlıklı, 30 ve üstü şişman olarak değerlendirilmiştir $(10,11)$.

Sistolik ve diyastolik kan basınçları üç farklı zamanda değerlendirilmiş, Park ve ark. (12) tanımladığı persantil eğrilerine göre öğrencilerin kan basınç persantilleri belirlenmiştir. Yaşa ve cinse göre sistolik ve diyastolik kan basıncının 95. persantil üzerinde oluşu kan basıncı yüksekliği olarak tanımlanmaktadır.

Öğrencilerin biyoelektrik impedans analizi (BIA) Tanita TBF $300 \mathrm{M}$ ile yapılmıştır. Biyoimpedans analizinde, bedene ayak elektrotları aracılığı ile $50 \mathrm{kHz}$ elektrik akımı gönderilerek vücut analizi yapılır. Biyoelektrik impedans analiz ölçümü, öğrencilerin sabah aç olması, menstrüasyon döneminde olmaması, 24-48 saat öncesinde aşırı fiziksel etkinlik yapmamış olması, aşırı su içmemiş olması ve son 24 saat içinde kafeinli içecekleri almamış olması gibi hususlar göz önünde bulundurularak yapılmıştır. Biyoelektrik impedans analiz ölçümü yapılırken, kişinin üzerinde metal bulundurulmamıştır. Biyoelektrik impedans analiz cihazı, boy, cinsiyet ve yaş gibi değişkenlere göre ölçüm yapmaktadır. Bireyin sessiz ve hareketsiz olarak ölçümü alınmıştır. Böylece VKI, bazal metabolizma hızı (BMH), yağ dokusu, yağsız doku, beden suyu ve impedansları bulunmuştur (13).

Vücut imgesinin belirlenmesi amacıyla ergen kızlara soru formu yardımıyla kendilerini nasıl hissettikleri (zayıf, normal, şişman) sorulmuş, alınan yanıt persantil eğrileriyle değerlendirilen, gerçek durumları ile karşılaştırılmıştır. Günlük besin tüketimleri ise bir günlük hatırlama-sorgulama tekniği ile saptanmış, görüşme yapılan günün bir gün öncesinde tüketilen bütün yiyeceklerin ve içeceklerin miktarları ile kaydedilmeleri istenmiştir.

Ergenlerin bir gün boyunca tükettikleri yiyecekler ve içecekler içerisine giren besinler ve miktarları standart yemek tarifeleri (14) kullanılarak hesaplanmış, elde edilen sonuçlar yaşa ve cinsiyete göre önerilen günlük tüketim standartları RDA (recommended daily allowment) göz önüne alınarak değerlendirilmiştir. Değerlendirmede kesişim noktaları (cut-off points) olarak önerilen günlük alım düzeyleri [(2/3=\%67 \%70) 土\%33] hesaplanmıştır. Enerji ve besin öğelerini önerilen düzeyde alanlar yeterli (\%67-133), önerilen değerin altında alanlar $(<\% 67)$ yetersiz, üzerinde alanlar da (>\%133) fazla tüketenler olarak kabul edilmiştir (13).

Ülkemizde, besin üretimi ve beslenme durumu dikkate alınarak günlük alınması gereken temel besinlerin planlanmasında dört besin grubu kullanılmaktadır. Bunlar; süt grubu, et-yumurta-kuru baklagil grubu, sebze ve meyve grubu, ekmek ve tahıl grubundan oluşmaktadır $(2,3)$. Ergenlerin soru formunda belirttikleri besin tüketim sıklıkları, besin grupları göz 
önüne alınarak değerlendirilmiştir. Ergenlerin besinlerin satın alınması ve hazırlanmasında besin tüketimi farkındalığını ve tutumlarını belirlemek için Likert tipi ölçek kullanılarak çeşitli sorular sorulmuş, yanıtlar katılıyorum ve katılmıyorum şeklinde kodlanmıştır. Çalışma yapılan iki okuldan, İlçe Milli Eğitim Müdürlüğü'nden anket ve bilgilendirme toplantıları için izin alınmıştır.

Çalışma tanımlayıcı nitelikte olup, elde edilen veriler SPSS 15.0 (Inc, Chicago, IL) kullanılarak bilgisayar ortamında değerlendirilmiştir. Çalışmada değişkenlerin normal dağılıma uygunluğu Kolmogorov-Smirnov testi ile incelendikten sonra, normal dağılım gösteriyorsa sonuçlar ortalama ve standart sapma, göstermiyorsa ortanca ve en küçük-en büyük olarak belirtilmiştir. Değişkenler arasındaki ilişkiler değişkenlerin normal dağılım gösterdiği durumlarda Pearson korelasyon testi, normal dağılım göstermediği durumlarda Spearman korelasyon testi ile değerlendirilmiştir. İstatiksel anlamlılık düzeyi $p<0,05$ olarak belirlenmiştir.

\section{Bulgular}

Çalışmaya katılan 14-17 yaşları arasındaki kızların $(n=172)$ yaş ortalaması 15,7 $\pm 0,9$ yıldır. Vücut ağırıkları, boy uzunlukları, VKI ortalamaları Tablo 1'de verilmiştir. Ergenler vücut ağırlıkları ve boy uzunlukları açısından değerlendirildiklerinde, sekiz öğrenci

Tablo 1. Ergenlerin antropometrik ve biyoimpedans analiz ölçüm sonuçları

\begin{tabular}{|l|c|}
\hline Ölçümler & Ortalama \pm SS \\
\hline Yaş (yıl) & $15,9 \pm 1,1$ \\
\hline Vücut ağırlı̆ı (kg) & $55,5 \pm 8,1$ \\
\hline Boy uzunluğu (cm) & $160,8 \pm 5,7$ \\
\hline Vücut kitle indeksi (kg/m) & $21,5 \pm 3,5$ \\
\hline Bel çevresi (cm) & $70,5 \pm 6,4$ \\
\hline Kalça çevresi (cm) & $94,2 \pm 6,4$ \\
\hline Bel/kalça & $0,7 \pm 0,1$ \\
\hline Bel/boy & $0,4 \pm 0,1$ \\
\hline Sistolik kan basıncı (mm Hg) & $102,6 \pm 13,5$ \\
\hline Diyastolik kan basıncı (mm Hg) & $62,0 \pm 8,9$ \\
\hline Bazal metabolizma hızı (kkal) & $1419,8 \pm 78,2$ \\
\hline Impedans (ohm) & $563,4 \pm 63,7$ \\
\hline Vücut yağ dokusu (kg) & $13,3 \pm 5,8$ \\
\hline Vücut yağ dokusu (\%) & $23,1 \pm 6,9$ \\
\hline Yağsız vücut dokusu (kg) & $42,3 \pm 3,5$ \\
\hline Yağsız vücut dokusu (\%) & $77,1 \pm 7,1$ \\
\hline Toplam vücut suyu (lt) & $31,0 \pm 2,5$ \\
\hline Toplam vücut suyu (\%) & $56,5 \pm 50,9$ \\
\hline
\end{tabular}

dışındaki öğrencilerin yaşlarına göre normal sınırlarda olduğu, üç öğrencinin 5. persantilin altında, beş öğrencinin de 95. persantilin üstünde olduğu saptanmıştır. Çalışmaya alınan 172 ergen kızın VKI değerlerine bakıldığında ise üç öğrencinin VKI persantiline göre düşük ağırlıklı, 19 öğrencinin kilolu, beş öğrencinin şişman olduğu, diğerlerinin ise normal sınırlarda olduğu görülmüştür ve öğrencilerin \%13,9'ünün kilolu ve şişman olduğu saptanmıştır.

Bel çevresi ölçümleri $(n=139)$ değerlendirildiğinde, 29 öğrencinin $(\% 20,9)$ bel çevresinin 90. persantilin üzerinde olduğu, kilolu ve şişman olan 24 öğrencinin hepsinin bel çevresinin 90. persantilin üzerinde olduğu görülmüştür.

Sistolik ve diyastolik kan basıncı $(n=138)$ değerlendirildiğinde ise, sistolik kan basıncının 19 öğrencide $(\% 13,9)$, diyastolik kan basıncının ise sekiz öğrencide $(\% 5,8) 95$. persantilin üzerinde olduğu, toplam 27 öğrencinin $(\% 19,6)$ sistolik ya da diyastolik kan basınçlarının 95. persantilin üzerinde olduğu saptanmıştır.

Ergenlerin bir kısmının ( $\mathrm{n}=92)$ biyoimpedans analiz sonuçları Tablo 1'de verilmiştir. Vücut yağ yüzdelerine göre 11 öğrencinin $(\% 14,5)$ şişman (yağ yüzdesi $\geq 30$ ), iki öğrencinin $(\% 2,6)$ düşük ağırlıklı (yağ yüzdesi <10) olduğu bulunmuştur. Vücut yağ yüzdesi persantilleri değerlendirildiğinde, 10 öğrencinin vücut yağ yüzdesinin 3. persantilin altında $(\% 13,1)$, üç öğrencinin 97. persantilin üstünde $(\% 3,9)$ ve 10 öğrencinin de beden yağ yüzdesinin 85 . persantilin üzerinde $(\% 13,1)$ olduğu bulunmuştur.

Ergenlerin vücut imgeleri bazı beslenme alışkanlıkları ve ailesel özelliklerinin dağılımı Tablo 2'de verilmiştir.

Ergenlerin bir günlük diyetle aldıkları enerji ve besin öğeleri ( $n=149$ ) Tablo 3’te verilmiştir. Çalışmaya alınan ergenlerin

Tablo 2. Ergenlerin vücut imgeleri, bazı beslenme alışkanlıkları ve ailesel özelliklerinin dağılımı

\begin{tabular}{|ll|c|c|}
\hline Değişkenler & & $\mathbf{n}$ & $\%$ \\
\hline Beden imgesi & Zayıf & 10 & 13,2 \\
& Normal & 53 & 69,7 \\
& Kilolu & 13 & 17,1 \\
\hline Ailede kilolu kişilerin varlığı & Var & 42 & 55,3 \\
& Yok & 34 & 44,7 \\
\hline Günlük öğün sayısı & $<3$ & 13 & 17,1 \\
& 3 & 50 & 65,8 \\
& $>3$ & 13 & 17,1 \\
\hline Kahvaltı alışkanlığı & Var & 46 & 60,5 \\
& Yok & 30 & 39,5 \\
\hline Ailede yüksek tansiyon varlığı & Var & 50 & 65,8 \\
& Yok & 26 & 34,2 \\
\hline \multirow{2}{*}{ Ailede şeker (Tip 2) hastalığı varlığı } & Var & 40 & 52,6 \\
& Yok & 36 & 47,4 \\
\hline Ailede aterosklerotik kalp hastalığı varlığı & Var & 29 & 38,2 \\
& Yok & 47 & 61,8 \\
\hline Ailede şişmanlık varlığı & Var & 41 & 53,9 \\
& Yok & 35 & 46,1 \\
\hline
\end{tabular}


günlük diyet ile aldıkları enerjinin kaynakları incelendiğinde, karbonhidrattan gelen oranlara bakıldığında, ergenlerin \%18,4'ünün \%55'den az, \%18,4'ünün \%55-60 arası, \%63,3'ünün $\% 60$ 'ın üzerinde olduğu, proteinden gelen oranlarına bakıldığında, ergenlerin \%5,3'ünün \%15-20 arasında, \%93,4'ünün \%15'in altında, \%1,3'ünün \%20'nin üzerinde olduğu, yağdan gelen oranlarına bakıldığında ise ergenlerin \%55,3'ünün \%20-30 arasında olduğu, \%32,9'unun \%30'dan fazla, \%11,8'inin ise \%20'nin altında olduğu saptanmıştır.

Ergenlerin enerji ve besin öğeleri tüketimlerinin RDA değerlerine göre yüzdeleri Tablo 4'te verilmiştir. Ergenlerin günlük dört besin grubu tüketim durumları $(n=169)$ (Tablo 5), günlük hazır besinleri tüketim durumları ise Tablo 6 'da verilmiştir.

Ergenlerin günlük ortalama 6,9 bardak su içtikleri saptanmıştır. Ergenlerin besin tüketimi konusundaki tutumları Tablo 7'de verilmiştir.

Ergenlerin kahvaltı yapma durumları ile VKi'leri arasında ilişki saptanmamıştır $(p=0,163)$. Kahvaltı yapma durumu ile diyetle alınan toplam enerji arasında anlamlı ilişki saptanmıştır $(p<0,05)$. Hiç kahvaltı yapmayan ergenlerin diyetle aldıkları toplam enerji ortalaması her zaman kahvaltı yapan ergenlere göre anlamlı derecede düşük bulunmuştur (rho=0,22, $p<0,05$ ). Alınan öğün sayısı ile günlük alınan enerji arasında pozitif ilişki saptanmıştır (rho= 0,29, $p<0,001$ ). Günlük alınan enerji ile VKi, $\mathrm{bel} / \mathrm{boy}$, bel/kalça ve bel çevresi arasında ilişki saptanmamıştır

\begin{tabular}{|l|c|}
\hline $\begin{array}{c}\text { Tablo 3. Ergenlerin bir günlük aldıkları enerji ve besin } \\
\text { öğeleri ve besin öğelerinin toplam enerjiye } \\
\text { katkılarının ortalama ve standart sapma değerleri }\end{array}$ \\
\hline Besin Öğeleri ( $\mathbf{n = 7 6 )}$ & $\mathbf{X} \pm \mathbf{S S}$ \\
\hline Enerji & $1927,5 \pm 640,1$ \\
\hline Karbonhidrat (gr) & $296,9 \pm 112,3$ \\
\hline Karbonhidrat (\%) & $61,1 \pm 9,4$ \\
\hline Protein (gr) & $50,9 \pm 21,1$ \\
\hline Protein (\%) & $10,5 \pm 2,9$ \\
\hline Yağ (gr) & $60,4 \pm 24,2$ \\
\hline Yağ (\%) & $28,4 \pm 8,8$ \\
\hline
\end{tabular}

Tablo 4. Ergenlerin enerji ve besin öğeleri alımlarııı RDA değerlerine göre tüketim durumları

\begin{tabular}{|l|c|}
\hline Besin Öğeleri & $\begin{array}{c}\text { RDA değerlerine göre tüketim durumu (\%) } \\
\mathbf{X} \pm \text { SS }\end{array}$ \\
\hline Enerji & $85 \pm 2,8$ \\
\hline Karbonhidrat & $106 \pm 16$ \\
\hline Protein & $93 \pm 4,2$ \\
\hline
\end{tabular}

RDA: recommended daily allowment (sırası ile $p=0,524, p=0,531, p=0,832, p=0,765)$. Günlük alınan toplam enerji ile protein miktarı $(g r)(r=0,786, p<0,001)$, proteinden alınan enerji $(r=0,787, p<0,001)$ ve yağdan alınan enerji $(r=0,737, p<0,001)$ arasında anlamlı ilişki bulunmuştur.

Çalışmamızda ergenlerin vücut imgeleri ile VKi'leri karşılaştııılığında gerçekte şişmanken kendini zayıf hissedenlerin oranı \%10,31, şişmanken kendini normal hissedenlerin oranı ise $\% 15,87$ olarak bulunmuştur $(n=126)$.

\section{Tartışma}

Günümüzde beslenme ile ilişkili hastalıkların artmasından dolayı sağıkı beslenmenin önemi de artmaktadır. Erişkinlerde olduğu gibi çocukluk ve ergenlik çağında da şişmanlık sıklığı giderek artmaktadır. Çocukluk dönemindeki şişmanlık oranı erişkin dönemdeki şişmanlık oranını önemli ölçüde etkilemektedir. Dünya genelinde okul çağındaki çocukların \%10'nun fazla kilolu olduğu bilinmektedir (2). Birçok ülkede çocukluk çağı şişmanlığı 1990'lardan sonra çarpıcı biçimde artmakta ve gelişmiş ülkelerde çocukların her yıl \%1'i fazla kilolu gruba eklenmektedir (15).

Çocukluk ve ergenlik döneminde kilolu olma ve şişmanlığın ayrıca erişkin dönemde erken yaşlanma ve fiziksel hastalık ile ilişkisi vardır (16). Çalışmamızda kilolu ve şişman olanların oranı \%13,9 bulunmuştur. Çalışmada yalnız kız öğrencilerin yer alması ve kız öğrencilerin vücut ağırlığı konusunda erkeklere

Tablo 5. Ergenlerin günlük dört besin grubu tüketim durumları

\begin{tabular}{|l|c|c|}
\hline Besin grupları & $\begin{array}{c}\text { Günlük tüketim } \\
\text { durumu }\end{array}$ & $\%$ \\
\hline Et grubu (et, yumurta, kuru baklagil) & $\begin{array}{c}\text { Evet } \\
\text { Hayır }\end{array}$ & 71 \\
\hline Süt grubu (süt, yoğurt, peynir) & Evet & 29,3 \\
& Hayır & 70,7 \\
\hline Ekmek ve tahıl grubu (ekmek, pilav, makarna) & Evet & 95 \\
& Hayır & 5 \\
\hline Taze sebze ve meyve grubu & Evet & 38,8 \\
& Hayır & 61,2 \\
\hline
\end{tabular}

Tablo 6. Ergenlerin günlük hazır besin tüketim durumları

\begin{tabular}{|l|c|}
\hline Hazır besinler & $\%$ \\
\hline Işlenmiş et ürünleri (sucuk, salam, sosis) & 53 \\
\hline Kola, gazoz, hazır meyve suları & 39,2 \\
\hline Ketçap, mayonez, krema gibi hazır soslar & 38,7 \\
\hline Cipsler, patates kızartması & 32,1 \\
\hline Çikolata, pasta, bisküviler & 36,6 \\
\hline Hamburger, pizza & 4,2 \\
\hline
\end{tabular}




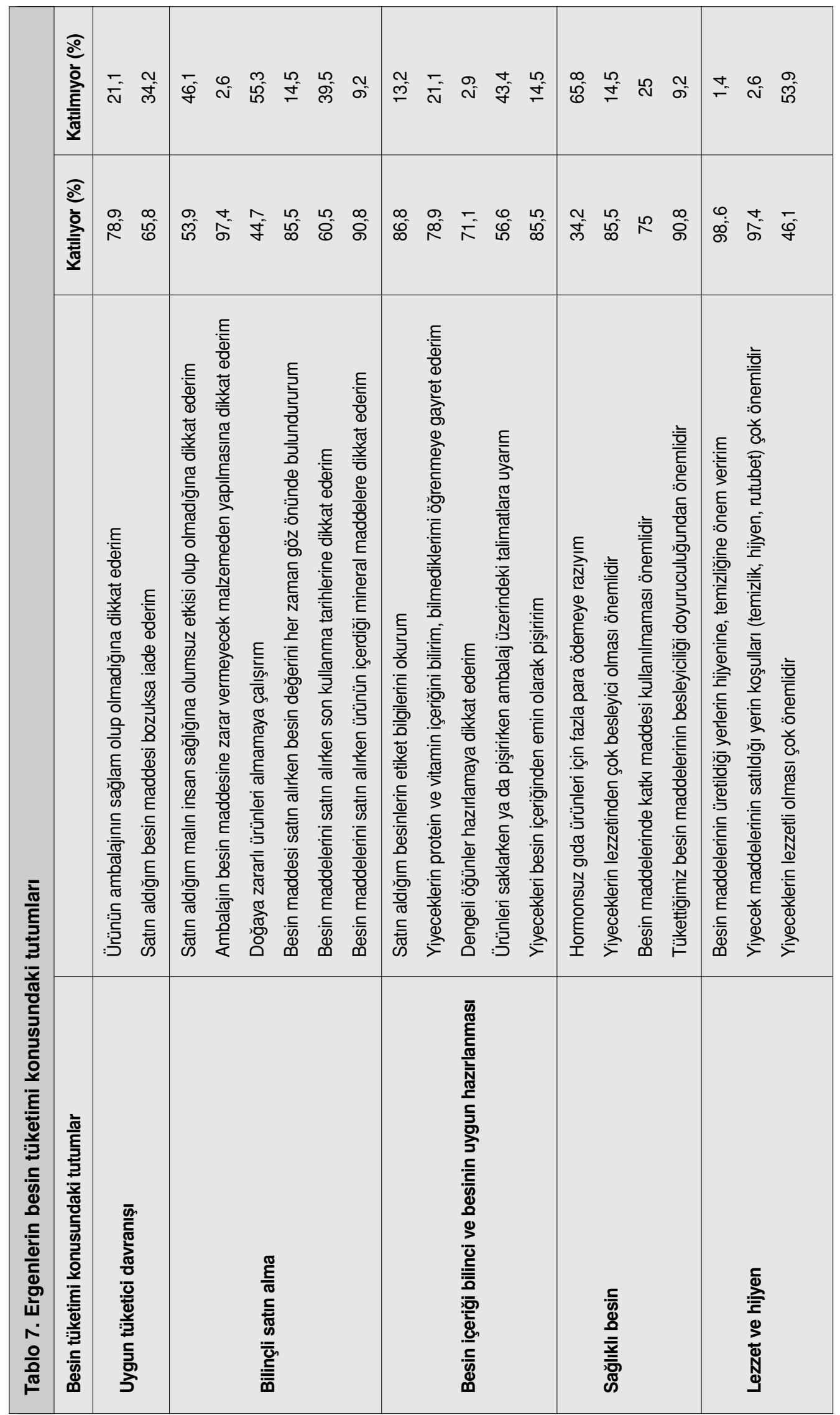


göre daha duyarlı olmaları yanında, çalışmanın sağlık meslek lisesinde gerçekleştirildiği göz önüne alındığında bu oran oldukça yüksektir. Pileggi ve ark. (17) 6-18 yaş arası 603 öğrenci üzerinde yaptıkları çalışmada öğrencilerin \%11,1'inin şişman olduğunu saptayarak çalışmamıza benzer bir sonuç elde etmişlerdir. Ogden ve ark. (18) ise ergenlerin yaklaşık $\% 16$ 'sının VKi'lerinin 95. persantilin üstünde, \%34'ünün ise VKl'lerinin 85. persantilin üstünde olduğunu saptamışlardır.

Çalışmamızda ergenlerin \%1,7'sinin VKi değerleri $<5$. persantilin, \%2,9'unun VKI değerleri >95. persantilin, \%11'inin VKI değerleri: 85-95. persantiller arasında olduğu belirlenmiş, VKI değerleri <5. ve VKI değerleri >95. persantil olanların oranının oldukça düşük bulunmasının olgu sayısının azlığından kaynaklanmış olabileceği düşünülmüştür.

Kurtoğlu ve ark. (9) çalışmasında 6-18 yaş grubundaki kız çocuklarının \%17,5'inin vücut yağ yüzdesinin 85 . persantilin üzerinde olduğu bulunmuştur. Çalışmamızda vücut yağ yüzdesi persantillerine göre ergen kızların vücut yağ yüzdeleri 85 . persantilin üzerinde olanların oranı daha düşüktür $(\% 13,1)$.

Bel/kalça oranı ve bel çevresi ölçümü, vücuttaki yağ dağılımının belirlenmesi için en sık kullanılan antropometrik ölçümlerdendir ve son yıllarda kronik hastalık riskini tanımlayan metabolik sendrom oluşma riskinin bir belirleyicisi olarak kullanılmaktadır (19). Ayrıca yayınlarda metabolik sendroma eşlik eden risk etkenleri, bel çevresinin 70 . ve 75 . persantil üzerinde oluşuyla ilişkili bulunmuştur $(8,20)$. Çalışmamızda ergenlerin \%20,9'unun bel çevresinin 90. persantilin üzerinde olduğu saptanmıştır. Bu durum çalışmamızdaki ergen kızların metabolik sendrom açısından ciddi oranda risk altında olduklarını göstermektedir. Çiçek ve ark. (21), 14-17,9 yaş 2737 kız öğrencilerin bel çevresini $(66,9 \pm 6,5 \mathrm{~cm})$ çalışmamızdakinden $(70,5 \pm 6,4 \mathrm{~cm})$ daha düşük bulmuşlardır.

Metabolik sendrom ölçütlerinden biri de sistolik ve diyastolik kan basıncının yüksekliğidir $(22,23)$. Çalışmamızda ergen kızların \%19,6'sında sistolik ya da diyastolik kan basıncı yüksek bulunmuştur. Pileggi ve ark. (17) öğrencilerin \%3,5'inde kan basıncı yüksekliği olduğunu saptamışlardır.

Bel/boy oranı merkezi şişmanlık tanısında bel çevresi gibi değerli bir belirteçtir. Bu oran yaş ve cinsiyetten bağımsız olarak şişman bireylerdeki metabolik ve kardiyovasküler riski belirler $(8,24,25)$. Bizim çalışmamızda bel/boy oranı Çiçek ve ark. (21) 14-17,9 yaş kızlar üzerinde yaptıkları çalışma sonucu $(0,44 \pm 0,04)$ ile benzer bulunmuştur.

Ergenlerin kişisel özelliklerine bakıldığında gerçekte şişmanken kendini zayıf hissedenlerin oranı \%10,31, şişmanken kendini normal hissedenlerin oranı \%15,87'dir. Bu da çalışmamızdaki ergenlerin bir kısmının vücut imgelerinin bozuk olduğunu göstermektedir. Türk ve ark. (26) 14-18 yaş lise birinci sını öğrencileri üzerine yaptıkları çalışmada öğrencilerin \%33,1'inin kendilerini kilolu bulduğunu saptamışlardır. Çalışmamızda sadece kızların yer almaları ve kız öğrencilerin vücut ağırlığı konusunda erkeklere göre daha duyarlı oldukları bilinmesine rağmen elde ettiğimiz sonuç oldukça şaşırtıcıdır.
Çalışmamızda ergenlerin zayıflamak için diyet yapma oranının (\%6) Özmen ve ark. (27) yaş ortalaması 16,6 60,7 yıl olan ve yarısı kızlardan oluşan 2146 öğrenci üzerinde yaptıkları çalışma sonucu ile $(\% 6,6)$ benzer olduğu görülmektedir. Ancak çalışmamızda zayıflamak için diyet yapanların çoğunun VKi persantillerinin 25-75 arasında olduğu (normal vücut ağırlığında) görülmüştür.

Günün en önemli öğünü olan kahvaltının, yaş ve eğitim düzeyi artıkça yaşanan yoğunluğa bağlı atlanılan bir öğün haline geldiği söylenebilir. Oysa kahvaltı fiziksel büyüme ve gelişmenin yanı sıra okul başarısına etkisi olduğu kanıtlanmış bir öğündür (28). Çalışmamıza katılan ergenlerin kahvaltı etmedikleri saptanmıştır. Yapılan çalışmalarda sabah kahvaltııının düzenli yapılmamasının bilişsel işlevlerde ve özellikle hatırlama yetisinde gerilemeye yol açı̆ı̆ı gösterilmiştir (28). Çalışmamızda ergenlerin yaklaşık beşte ikisinin her gün kahvaltı yapmadığı saptanmış, bu durumun yapılan diğer çalışmalarla benzerlik gösterdiği görülmüştür (21). Çalışmalarda, ilkokul döneminde yüksek olan düzenli kahvaltı yapma alışkanlığı oranı üniversite dönemlerine doğru gittikçe düşmektedir $(29,30)$. Ergen kızların düzensiz kahvaltı alışkanlığı, ağılık kontrolünü sağlamaya yönelik geliştirilen bir davranış olabilir ya da sabah evden çıkarken hazırlık için daha fazla zaman harcamalarından dolayı kahvaltı etmeye fırsat bulamamalarından kaynaklanabilir.

Çalışmamızda ergenlerin kahvaltı yapma durumları ile VKi'leri arasında, günlük alınan enerji ile VKI, bel/boy, bel/kalça ve bel çevresi arasında anlamlı ilişki bulunmamış olsa da aslında bunun olgu sayısı azlığından kaynaklanabileceği düşünülebilir. Fenandez Moralez ve ark. (31) 15-17 yaş 467 ergeni içeren çalışmalarında VKi ile kahvaltıda enerji alımı arasında ters ilişki saptamışlardır.

Çalışmamızda ergenlerin yaklaşık yarısının ailesinde kan basıncı yüksekliği, şeker hastalığı (Tip II) şişmanlık, koroner arter hastalığı olduğu saptanmıştır. Bizim çalışmamızda bu oran yapılan benzer çalışmaların (25) sonuçlarından biraz daha yüksek bulunmuştur.

Sağlıkı, dengeli ve yeterli beslenmede su çok önemlidir. Günlük yiyecek ve içeceklerde bulunan su miktarının 2 It olması yeterlidir. Ancak çalışma tarzına göre ve sıcak havada günde 3 ve hatta 10 It gerekebilir (32). Çalışmamızda ergen kızların önerilenin altında su tükettikleri, bu durumun çalışmanın yapıldığı mevsimin kış olmasından kaynaklanabileceği düşünülmüştür. Sıvı tüketiminin artırılmasının istirahatteki enerji tüketiminin artmasına dolayısıyla kilo kaybının artmasına neden olduğu yapılan çalışmalarla gösterilmiştir (33).

Sağlıklı ve dengeli beslenmek için kullanılan diyet enerjisinin \%55-60'sının karbonhidrattan, \%15-20'sinin protein ve \%2530 'unun yağdan gelmesi gerektiği bilinmektedir (2). Çalışmamızda enerjinin karbonhidrattan gelen oranının yüksek, proteinden gelen oranının düşük olduğu belirlenmiştir. Ergenlerin enerji ve besin öğesi alımlarının önerilen değerlerin $\% 67$ 'sinin altında olması yetersiz, \%67-133 arasında olması 
yeterli, \%133'ün üzerinde olması da fazla alım olarak değerlendirilmektedir (13). Buna göre ergen kızların yaklaşık üçte birinin enerji tüketimlerinin yetersiz olduğu saptanmıştır. Ergen kızların çoğunun yeterli düzeyde karbonhidrat tükettikleri, ancak öğrencilerin yarısından fazlasının proteini yetersiz düzeyde aldıkları saptanmıştır. Yağmur (34) ve Şanlıer ve ark. (35) çalışmalarında üniversite öğrencilerinin enerji ve karbonhidratı yetersiz tükettikleri saptanmıştır. Çelik ve Tokgöz (36) 18-20 yaş arası öğrenciler üzerinde yaptıkları çalışmada kızların $58,7 \pm 21,9 \mathrm{~g}$ protein, $63,3 \pm 22,9 \mathrm{~g}$ yağ aldıklarını saptamışlardır. Bizim çalışmamızda ise protein tüketiminin daha düşük, yağ tüketiminin ise benzer olduğu görülmüştür. Ancak Hanning ve ark. (37) 315 erkek 346 kız ergen üzerinde yaptıkları çalışmada ergenlerin aldıkları toplam enerjinin protein (\%15) ve yağdan (\%31) gelen oranının bizim çalışmadan daha yüksek olduğunu, karbonhidrattan (\%54) gelen oranının ise daha düşük olduğunu göstermişlerdir. Dapi ve ark. (38) 12-16 yaş ergenlerin \%50'sinden fazlasının proteini, \%26'sının yağları önerilenden az tükettiklerini, \%26'sının ise yağları önerilenin üzerinde tükettiklerini bulmuşlardır. Çalışmamızda protein tüketiminin düşük bulunmasının öğrencilerin sosyoekonomik düzeylerinden kaynaklandığı düşünülebilir.

Sağlıklı beslenme çerçevesinde et, süt, tahıl, taze sebze ve meyve grubunun her birinin her gün tüketilmesi gerekmektedir (13). Büyüme ve gelişmenin en hızlı olduğu ergenlik döneminde bu durum daha da önem kazanmaktadır (2). Çalışmamızda ergenlerin günlük dört besin grubunu tüketme durumları incelendiğinde, \%83'ünün et grubunu, \%70,7'sinin süt grubunu, $\% 80,5$ 'inin tahıl grubunu, \%61,2'sinin taze sebze ve meyve grubunu her gün tüketmedikleri belirlenmiştir.

Çalışmamızda ergen kızların yarısından fazlasının çikolata, pasta, bisküvi, üçte birinin cips, patates kızartması, kola, gazoz, hazır meyve suları gibi sağlıksız besinleri tükettikleri belirlenmiştir. Bu sonuç öğrencilerin aldıkları eğitimin tutum ve davranışlarında değişikliğe bir etkisi olmadığını göstermesi açısından önemlidir. Ancak Demirezen ve ark. (4) çalışmasında sağlıksız beslenen öğrenci oranı çok daha yüksektir $(\% 98,8)$. Türk (26) ve ark. 14-18 yaş ergenleri içeren çalışmalarında, sağlıksız besinler içinde en sık tüketilenlerin çalışmamızda olduğu gibi hazır kek/bisküvi, ketçap/mayonez, kızartma, salam, sosis ve cips olduğu görülmektedir.

Çalışmamızda ergenlerin çoğu $(\% 84,2)$ besin maddelerinin satın alınmasında besin ürününün fiyatının önemli olduğunu düşünmektedir. Bu durumun çalışmamıza katılan öğrencilerin sosyoekonomik düzeyi düşük olan bölgede yaşamalarından kaynaklanmış olabileceği düşünülmüştür. Yapılan çalışmalar da sosyoekonomik düzeyin besinin fiyatına verilen önemi arttırdığını göstermektedir $(39,40)$.

Çalışmamızda ergenlerin yaklaşık üçte birinin besin içeriği bilinci ve besinin uygun hazırlanması konusunda uygun olmayan tutum gösterdikleri görülmüştür (Tablo 7). Topuzoğlu ve ark. (41) çalışmalarında da benzer sonuçlar bulunmuştur. Chang ve ark. (42) ise \%17,1'inin yeme tutum ve davranışlarının bozuk olduğunu saptamışlar ve bu tutum ve davranışların ergenlerin beslenme durumlarını tehlikeye attığını vurgulamışlardır.

Bu çalışma ergen kızların besin tüketimlerindeki, beslenme alışkanlıklarındaki, besin tüketim tutumlarındaki eksiklikleri ortaya koyması nedeniyle de önem taşımaktadır. Bu nedenle okullarda beslenme eğitim programlarının düzenli ve devamlı olarak düzenlenmesi önemlidir.

Çalışmamızın sonuçlarından biri de ergen kız öğrenci grubundaki şişmanlık ve yüksek kan basıncı oranlarının belirlenmiş olmasıdır. Çalışmamız olgu sayısı genel değerlendirme yapmak için yeterli olmasa da ergen gruptaki kahvaltı yapmama, öğün atlama ve besin öğelerinin dengesiz alımı gibi genel beslenme alışkanlıklarına dikkat çekmiştir. Ergenlerin yaklaşık üçte birinin besin tüketimi konusunda uygun olmayan tutum ve davranış gösterdikleri, besin içeriği konusunda bilinçsiz oldukları görülmüştür. Sporcu gençleri ele alan uluslararası çalışmalarda da beslenme konusundaki bilgi yetersizliğine dikkat çekilmiş ve beslenme konusundaki bilgi düzeyi ile beslenme alışkanlığı arasında ilişki olmadığı vurgulanmıştır $(43,44)$.

Özellikle sağlık meslek lisesi öğrencilerinin kahvaltı yapma, öğün atlamama, besin gruplarının dengeli alımı gibi genel beslenme alışkanlıkları, besin içeriği ve besin tüketimi konularında uygun tutum ve davranışları kazanmaları gereklidir. Sağlık hizmeti verecek ve halkın sağlığının düzeltilmesi ya/ya da korunmasında görev alıp, bu alanda halka örnek olacak öğrencilerin bilgi ve alışkanlıklarındaki eksiklik ve uygunsuzlukların saptanmış olması önemlidir. Toplum sağlığı açısından bu grubu öncelikli bir grup olarak ele almak gerektiğini düşünmekteyiz.

\section{Çıkar çatışması: Bildirilmemiştir.}

\section{Kaynaklar}

1. Demir GC. Okul çağı çocukları ve adolesan beslenmesi. Türkiye Klinikler J Pediatr Sci 2005; 1: 25-30.

2. Baysal A. Beslenme. Besin grupları. 12. baskı. Ankara: Basım ve Yayım San. Tic. Ltd. Şti, 2009: 267-96.

3. Toprak I, Bunsuz O, Sentürk S, ve ark. Toplumun beslenmede bilinçlendirilmesi Sağlık Bakanlığı, Hacettepe Üniversitesi. Saha personeli için toplum beslenmesi programı eğitim materyali 3. Basım, Ankara: Onur Matbacilık 2002: 110-4.

4. Demirezen E, Coşansu G. Adolesan çağı öğrencilerde beslenme alışkanlıklarının değerlendirilmesi. Sürekli Tıp Eğitim Dergisi 2005; 14(8): 174.

5. Ozturk A, Mazicioglu MM, Hatipoglu N, et al. Referance body mass index curves for Turkish children 6 to 18 years of age. J Pediatr Endocrinol Metabolism 2008; 21: 827-36.

6. Lahti-Koski M, Gill T. Defining childhood obesity. In: Kiess W, Marcus C, Wabitsch M, (eds.) Obesity in childhood and adolescence. Basel: Karger, 2004; 9: 1-19.

7. Hatipoglu N, Ozturk A, Mazicioglu MM, Kurtoglu S, Seyhan S, Lokoglu F. Waist circumference percentiles for 7- to 17-year-old Turkish children and adolescents. Eur J Pediatr 2008; 167: 383-9.

8. Savva SC, Tornaritis M, Savva ME, et al. Waist circumference and waist-to-height ratio are better predictors of cardiovascular disease risk factors in children than body mass index. Int $\mathrm{J}$ Obes Relat Metab Disord 2000; 24: 1453-8.

9. Kurtoglu S, Mazicioglu MM, Ozturk A, Hatipoglu N, Cicek B, Ustunbas HB. Body fat reference curves for healthy Turkish children and adolescents. Eur J Pediatr 2010; 169(11): 1329-35. 
10. Antal M, Péter S, Biró L, et al. Prevalence of underweight, overweight and obesity on the basis of body mass index and body fat percentage in Hungarian schoolchildren: representative survey in metropolitan elementary schools. Ann Nutr Metab 2009; 54: 171-6.

11. Williams DP, Going SB, Lohman TG, et al. Body fatness and risk for elevated blood pressure, total cholesterol and serum lipoprotein ratios in children and adolescents. Am J Public Health 1992; 82: 358-63.

12. Park MK, Menard SW, Yuan C. Comparison of blood pressure in children from three ethnic groups. Am J Cardiol 2001; 87:1305-8.

13. Baysal A, Aksoy M, Besler HT, ve ark. Diyet el kitabı. 4. Baskı. Ankara: Hatiboğlu Yayınevi Şahin Matbaası, 2002.

14. Kutluay T. Standart yemek tarifeleri. Toplu beslenme yapılan kurumlar için standart yemek tarifeleri. 1. Baskı. Ankara: Cihan Matbaası, 1991.

15. Hatun S, Çizmecioğlu F. Çocuklarda metabolik sendrom. Çocuk Sağlığı ve Hastalıkları Dergisi 2005; 48: 257-65.

16. Reilly JJ, Kelly J. Long-term impact of overweight and obesity in childhood and adolescence on morbidity and premature mortality in adulthood: systematic review. Int J Obes 2011; 35(7): 891-8.

17. Pileggi C, Carbone V, Nobile CG, Pavia M. Blood pressure and related cardiovascular disease risk factors in 6-18 year-old students in Italy. $J$ Paediatr Child Health 2005; 41(7): 347-52.

18. Ogden CL, Carroll MD, Curtin LR, et al. Prevalence of overweight and obesity in the United States, 1999-2004. JAMA 2006; 295: 1549-55.

19. Baysal A, Baş M, (ed.) Yetişkinlerde ağırlık yönetimi. Birinci basım. Ankara: Türkiye diyetisyenler yayını, Ekspres baskı A.Ş, 2008.

20. Moreno LA, Pineda I, Rodríguez G, Fleta J, Sarría A, Bueno M. Waist circumference for the screeningof the metabolic syndrome in children. Acta Paediatr 2002; 91: 1307-12.

21. Cicek, B, Ozturk A, Mazicioglu MM, et al. A novel cut-off for abdominal obesity derived from various anthropometric indices to predict body composition: Arm fat area. Turk J Med Sci 2010; 40(4): 515-23.

22. lannuzzi A, Licenziati MR, Acampora $C$, et al. Carotid artery stiffness in obese children with the metabolic syndrome. Am J Cardiol 2006; 97: 528-31.

23. Atabek ME, Pirgon O, Kurtoglu S. Prevalence of metabolic syndrome in obese Turkish children and adolescents. Diabetes Res Clin Pract 2006; 72: 315-21.

24. Kahn HS, Imperatore G, Cheng YJ. A population-based comparison of BMI percentiles and waist-to-height ratio for identifying cardiovascular risk in youth. J Pediatr 2005; 146: 482-8.

25. Maffeis C, Banzato C, Talamini G. Obesity study group of the Italian society of pediatric endocrinology and diabetology. Waist-to-height ratio, a useful index to identify high metabolic risk in overweight children. J Pediatr 2008; 152: 207-13.

26. Türk M, Gürsoy T, Ergin I. Kentsel bölgede lise birinci sınıf öğrencilerinin beslenme alışkanlıkları. Genel Tıp Dergisi 2007; 17: 81-7.

27. Özmen D, Cetinkaya AC, Ergin D, ve ark. Lise öğrencilerinin yeme alışkanlıkları ve beden ağırlığını denetleme davranışları. TSK Koruyucu Hekimlik Bülteni 2007; 6(2): 98-105.

28. Baysal A. Kahvaltı ve okul başarısı. Beslenme ve Diyet Dergisi 1999; 28: 1-3.

29. Mazıcıoglu M, Oztürk A. Üniversite 3. ve 4. sınıf öğrencilerinde beslenme alışkanlıkları ve bunu etkileyen faktörler. Erciyes Tıp Dergisi 2003; 25: 172-8.
30. Önder FO, Kurdoğlu M, Oğuz G, ve ark. Gülveren Lisesi son sınıf öğrencilerin bazı beslenme alışkanlıklarının ve bunun malnütrisyon prevelansı ile olan ilişkisi. Hacettepe Toplum Hekimliği Bülteni 2000; 21(1): 1-5.

31. Fernández Morales I, Aguilar Vilas MV, Mateos Vega CJ, Martínez Para MC. Breakfast quality and its relationship to the prevalence of overweight and obesity in adolescents in Guadalajara (Spain). Nutr Hosp 2011; 26(5): 952-8.

32. Ekin İ. A'dan Z'ye dengeli beslenme. Spor Med Yayınları No:1. 3. basım. Ankara: EMO Teknik malzeme Tic. San. Ltd. Sti 1996: 197-204.

33. Dubnov-Raz G, Constantini NW, Yariv H, Nice S, Shapira N. Influence of water drinking on resting energy expenditure in overweight children. Int J Obes (Lond) 2011; 35(10): 1295-300.

34. Yagmur C. Çukurova Üniversitesi öğrencilerinin beslenme durumu üzerine bir araştırma. Beslenme ve Diyet Dergisi 1995; 24: 238-51.

35. Şanlıer N, Arlı M. Üniversitede okuyan ve beslenme eğitimi alan kız öğrencilerin beslenme durumları günlük enerji alımları ve harcamaları. Gazi Beden Eğitimi ve Spor Bilimleri Dergisi 2000; 5: 21-30.

36. Celik F, Tokgöz P. Dicle Üniversitesi beden eğitimi ve spor bölümünde okuyan öğrencilerin besin tüketim düzeyleri ve beslenme alışkanlıkları. Beslenme ve Diyet Dergisi 1999; 28: 4-9.

37. Hanning RM, Woodruff SJ, Lambraki I, Jessup L, Driezen P, Murphy CC. Nutrient intakes and food consumption patterns among Ontario students in grades six, seven, and eight. Can J Public Health 2007; 98(1): $12-6$.

38. Dapi LN, Hörnell A, Janlert U, Stenlund H, Larsson C. Energy and nutrient intakes in relation to sex and socio-economic status among school adolescents in urban Cameroon, Africa. Public Health Nutr 2011; 14(5): 904-13.

39. Satia JA, Galanko JA, Neuhouser ML. Food nutrition label use is associated with demographic, behavioral, and psychosocial factors and dietary intake among African Americans in North Carolina. J Am Diet Assoc 2005; 105: 392-402.

40. Kearney M, Kearney J, Dunne A, Gibney M. Sociodemographic determinants of perceived influences on food choice in a nationally representative sample of Irish adults. Public Health Nutr 1999; 3: 219-26.

41. Topuzoglu $A$, Hıdıroglu $S$, Ay $P$, ve ark. Tüketicilerin gıda ürünleri ile ilgili bilgi düzeyleri ve sağlık risklerine karşı tutumları. TSK Koruyucu Hekimlik Bülteni 2007; 6(4): 253-8.

42. Chang YJ, Lin W, Wong Y. Survey on eating disorder-related thoughts, behaviors, and their relationship with food intake and nutritional status in female high school students in Taiwan. J Am Coll Nutr 2011; 30(1): 39-48.

43. Walsh M, Cartwright L, Corish C, Sugrue S, Wood-Martin R. The body composition, nutritional knowledge, attitudes, behaviors, and future education needs of senior schoolboy rugby players in Ireland. Int $\mathrm{J}$ Sport Nutr Exerc Metab 2011; 21(5): 365-76.

44. Gacek M. Eating habits of a group of professional volleyball players. Rocz Panstw Zakl Hig 2011; 62(1): 77-82. 